\title{
Maternal and child health care: adequacy index in public health services
}

\author{
Assistência à saúde materno-infantil: índice de adequação em serviços públicos de saúde \\ Asistencia a la salud materno-infantil: índice de adecuación en servicios públicos de salud
}

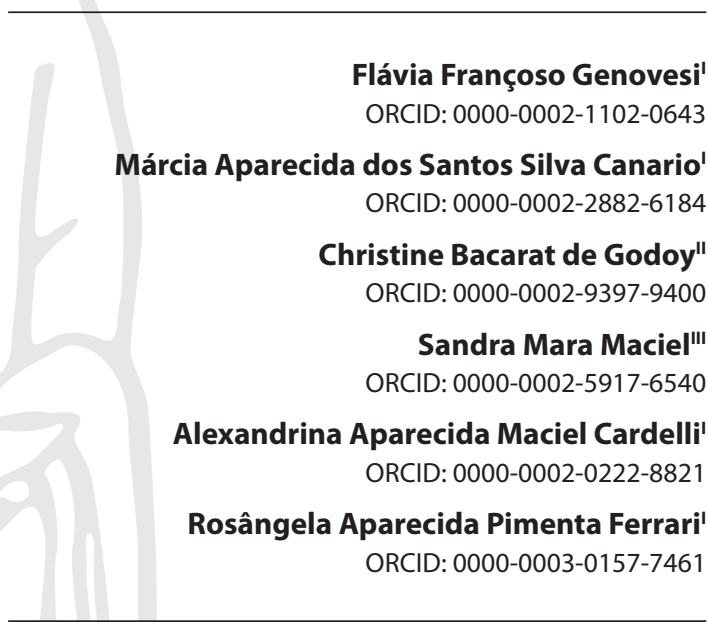

'Universidade Estadual de Londrina. Londrina, Paraná, Brazil. "Universidade Federal do Mato Grosso. Cuiabá, Mato Grosso, Brazil. "'Universidade Estadual de Maringá. Maringá, Paraná, Brazil.

How to cite this article: Genovesi FF, Canario MASS, Godoy CB, Maciel SM,

Cardelli AAM, Ferrari RAP. Maternal and child health care: adequacy index in public health services. Rev Bras Enferm. 2020;73(Suppl 4):e20170757. doi: http://dx.doi. org/10.1590/0034-7167-2017-0757

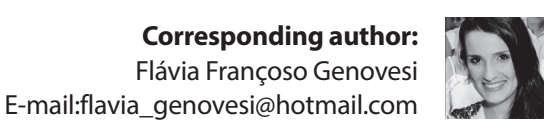

EDITOR IN CHIEF: Antonio José de Almeida Filho ASSOCIATE EDITOR: Cristina Parada

Submission: 03-08-2019

Approval: 04-23-2020

\section{ABSTRACT}

Objectives: to analyze the adequacy of maternal and child-care in prenatal care, childbirth and the puerperal period, in the public health service. Methods: longitudinal study carried out in a city in Paraná with 357 puerperal women in a public maternity ward, outpatient clinic for immediate puerperal return and home visit 42 days postpartum. Four care domains were grouped (1 - Prenatal, 2 - Maternity, 3 - Immediate puerperal return, 4 - Late puerperal return). Mean median, standard deviation and coefficient of variance were calculated considering adequate assistance when $\geq 70 \%$; and inadequate, inferior. Results: lowest suitability average in Domain 3 (39.37\%) and highest for Domain 4 (74.82\%); median of $50.00 \%$ at 3 and $76.90 \%$ at 4 . The largest standard deviation, in Domain 3 (25.18\%); and high coefficient of variance for 1 and 3. Conclusions: in maternal and child follow-up, rates close to adequate in maternity care and higher in late puerperal return, meanwhile prenatal and immediate puerperal return were below the recommended in the health care network.

Descriptors: Child Health; Women's Health; Program Evaluation; Health Systems Plans; Epidemiologic Studies.

\section{RESUMO}

Objetivos: analisar a adequação da assistência materno-infantil no pré-natal, parto e período puerperal, no serviço público de saúde. Métodos: estudo longitudinal realizado em cidade do Paraná com 357 puérperas em maternidade pública, ambulatório de retorno puerperal imediato e visita domiciliar 42 dias pós-parto. Agruparam-se quatro domínios de assistência (1 - Pré-natal, 2 - Maternidade, 3 - Retorno puerperal imediato, 4 - Retorno puerperal tardio). Calculou-se média, mediana, desvio-padrão e coeficiente de variância considerando assistência adequada quando $\geq 70 \%$; e inadequada, inferior. Resultados: menor média de adequação no Domínio 3 (39,37\%) e maior para o 4 (74,82\%); mediana de 50,00\% no 3 e 76,90\% no 4 . O desviopadrão maior, no Domínio $3(25,18 \%)$; e coeficiente de variância alta para 1 e 3 . Conclusões: no seguimento materno-infantil, índices próximos ao adequado no atendimento na maternidade e superior no retorno puerperal tardio, entretanto pré-natal e retorno puerperal imediato se apresentaram aquém do preconizado na rede de atenção à saúde.

Descritores: Saúde da Criança; Saúde da Mulher; Avaliação de Programas e Projetos de Saúde; Sistemas de Saúde; Estudos Epidemiológicos.

\section{RESUMEN}

Objetivos: analizar la adecuación de la asistencia materno-infantil en el prenatal, parto y período puerperal, en el servicio público de salud. Métodos: estudio longitudinal realizado en ciudad de Paraná con 357 puérperas en maternidad pública, ambulatorio de retorno puerperal inmediato y visita domiciliar 42 días postparto. Se ha agrupado cuatro dominios de asistencia ( 1 - Prenatal, 2 - Maternidad, 3 - Retorno puerperal inmediato, 4 - Retorno puerperal tardío). Se ha calculado media, mediana, desvío estándar y coeficiente de desviación considerando asistencia adecuada cuando $\geq 70 \%$; y inadecuada, inferior. Resultados: menor media de adecuación en el Dominio 3 (39,37\%) y mayor para 4 (74,82\%); mediana de $50,00 \%$ en 3 y $76,90 \%$ en 4 . El desvío estándar mayor, en el Dominio 3 (25,18\%); y coeficiente de desviación alta para 1 y 3. Conclusiones: en el seguimiento materno infantil, índices próximos al adecuado en la atención en la maternidad y superior en el retorno puerperal tardío, entretanto prenatal y retorno puerperal inmediato se presentaron lejos del preconizado en la red de atención a la salud. Descriptores: Salud del Niño; Salud de la Mujer; Evaluación de Programas y Proyectos de Salud; Sistemas de Salud; Estudios Epidemiológicos. 


\section{INTRODUCTION}

Public health policies in Brazil aimed at the maternal and child population have undergone a long process of (re)structuring in order to improve care and reduce rates of morbidity and mortality from causes considered preventable, through access to qualified services $^{(1)}$. In 2011, the infant mortality rate in Brazil had already decreased compared to previous years, but it was still high when compared to other countries ${ }^{(1-2)}$. Since then, the government has established a new strategy to change the model of maternal and child care, thus creating the Rede Cegonha ${ }^{(2)}$, which aims to promote and implement a new model in childbirth and birth care, the organization of the maternal and child care network with guaranteed access, reception and resolution and the reduction of maternal and child mortality ${ }^{(3)}$.

In Paraná, in 2012, the Rede Mãe Paranaense (RMP) was implemented, based on the general principles of Rede Cegonha ${ }^{(4-5)}$. In research carried out in three health regions in the state of Paraná, to assess the implementation of the RMP, some flaws in the process were identified, however the program has had a positive impact on maternal and child health indicators. It is known that there is still much to improve, focusing on the qualification of professionals, to enable the promotion of maternal and child health care in a resolute and efficient way ${ }^{(6)}$.

It is noteworthy that maternal and child-care should be carried out since prenatal care, continuing during childbirth and the puerperium. Therefore, in 2015, the National Policy for Comprehensive Child Health Care (PNAISC) was established, that defines the promotion and protection of the child's health with the objective of comprehensive pregnancy at 9 years of age. Among the principles of this policy, we highlight the wholeness of care, equity in health, the right to life and health, as well as universal access and humanization $^{(7)}$. Article 6, presents the seven strategic axes, one of which is humanized and qualified care for pregnancy, childbirth, birth and new-born, with a view to improving access, coverage, quality of obstetric and neonatal services through integration of prenatal, maternity and child care actions in primary care ${ }^{(7)}$.

The complete recommendation by the Unified Health System (SUS) is not a commitment of just one health professional or service, but is tangible by the principles of networking, listening to the needs of users, using resolutive measures and establishing links with the population ${ }^{(8)}$. Assistance to women and children is still under construction, with the paradigm shift from the diseasecentered model to a model focused on networks, the inclusion of family and society and comprehensive care ${ }^{(9)}$.

In this sense, after the implementation of these maternal and child health care networks, it is necessary to carry out evaluative studies to portray the possible gaps in pregnancy-puerperal care, pointing to the need for investigations to identify whether the actions recommended in the entire care cycle at different levels of care meet or not the program's regulations. Thus, subsidies can be provided to enhance the expected resolution.

\section{OBJECTIVES}

To analyze the adequacy of maternal and childcare in prenatal care, childbirth and the puerperal period, in the public health service.

\section{METHODS}

\section{Ethical aspects}

The present study is an excerpt from the research entitled "Risk factors for maternal and child morbimortality: from pregnancy to the first postpartum year", authorized by the Municipal Health Authority and approved by the Ethics Committee of the Universidade Estadual de Londrina (CEP/UEL).

\section{Study design, location and period}

This is a longitudinal study, carried out in a municipality located in the northern region of Paraná, between July and November 2014. In the survey, access to women was carried out at the public maternity hospital in the city, a reference for childbirth/gestation of habitual risk (HR) and intermediate risk (IR), exclusively for care by the Unified Health System (SUS) and with the title of Baby Friendly Hospital Initiative (BFHI).

\section{Population or sample}

The sample calculation was based on the 3,415 births in 2012, considering a margin of error of $5 \%$ and a confidence level of $95 \%$, resulting in 358 women. There was an exclusion due to the child's adoption, so the $n$ was 357 puerperal women. The inclusion criteria were: living in the urban area, having been pregnant with $H R$ and IR, being able to understand participation in the study as well as consenting to it.

The collection of research data occurred in four stages; and, in this study, the first three stages were investigated: at the maternity hospital, in medical records, the Pregnant Woman's Portfolio and an interview one day after delivery; at the outpatient clinic, observing the immediate postpartum return visit between 7 and 10 days after discharge from the maternity hospital; and on the first home visit (HV) 42 days postpartum, on late puerperal return. The data was collected in a form previously tested and completed by the researchers.

\section{Study protocol}

The variable "type of maternal and child care" was constructed based on the actions recommended in the protocols of the maternal and child care network ${ }^{(2-3)}$. They were classified as adequate $(\geq 70 \%)$ and inadequate $(<70 \%)$ and organized into four care groups: Group I: Prenatal care; Group II: Maternity care; Group III: Immediate postpartum visit (IPV); and Group IV: Late puerperal return (LPR).

For pre-natal care (PC), 15 variables were selected: planned pregnancy (1 yes; 2 - no), adequacy to prenatal care (1 - adequate and 2 - intermediate and inadequate), including the following variables, classified adequate (1) or intermediate/inadequate (2): beginning of prenatal care ( 1 - < 14 weeks; $2-\geq 14$ weeks); number of consultations ( 1 - $\geq 6$ consultations; 2 - $<6$ consultations); place of performance ( 1 - Basic Health Unit UBS; 2 - need to be referred to a reference service); guidance for childbirth (1 - received guidance on types of delivery, warning signs 
and rights of the pregnant woman; 2 - received no guidance); guidance on breastfeeding (BF) (1 - received guidance; 2 - did not receive); conducting the clinical obstetric examination (1 - blood pressure, breasts, uterine height and heart rate check; 2 - not performed); filling in the prenatal card, containing the information: prenatal problems (1 - yes; 2 - no), weight control chart ( 1 - yes; 2 - no), edema evaluation ( 1 - yes; 2 - no) and vaccination schedule - anti-tetanus ( 1 - yes; 2 - no), anti-hepatitis B (1 - yes; 2 - no); interval between last prenatal consultation and delivery ( 1 - $\leq 15$ days; 2 - $\geq 16$ days); previous visit to the maternity hospital ( 1 - yes; 2 - no).

Maternity care was divided into two stages: delivery room and shared accommodation, with 15 variables. In the delivery room assessed: type of delivery (1 - vaginal, 2 - caesarean), labor induction (1 - no, 2 - yes), intrapartum complications (1 - no, 2 yes), intact perineum ( 1 - yes , 2 - no), companion ( 1 - yes, 2 - no), early mother-baby contact ( 1 - occurred, 2 - did not occur), suction in the first postpartum hour (1 - yes, 2 - no) and guidance on breastfeeding (BF) in the delivery room (1 yes, 2 - no). In shared accommodation: referral of the new-born (NB) in the first hour ( 1 - yes, 2 no), breastfeeding on demand (1 - yes, 2 - no), problems with the breasts ( 1 - yes, 2 - no), intact nipples ( 1 - yes, 2 - no), NB weighing at hospital discharge (1 - yes, 2 - no), guidance for reference if problems with $\mathrm{BF}$ ( 1 - yes, 2 - no) and return to FHU at hospital discharge (1 - yes, 2 - no).

In the immediate puerperal return (IPR), up to 10 days postpartum, 16 variables were selected: care (1 - yes, 2 - no), health professional ( 1 - yes, 2 - no), general health assessment (standard sleep, emotional and hygiene conditions - 1 - yes, 2 - no), breast and nipple assessment (1 - yes, 2 - no), breastfeeding (1 - yes, 2 - no), weighing the NB (1 - yes, 2 - no), physical examination of the NB (1 - yes, 2 - no), neonatal-nursing scheduling and vaccines (1 - yes, 2 - no), other guidelines - care for intestinal colic, sunbathing, accident prevention, breastfeeding, neonatal nursing and vaccination, neonatal tests and family planning ( 1 - yes, 2 - no) and counter-referral (1 - yes, 2 - no).

In the late puerperal approach, in the home visit 42 days postpartum, 13 selected variables: received support from the health professional (1 - yes, 2 - no), relevance of the first consultation (1 important, 2 - do not know, do not think it important), attends the consultations - with nursing, doctor and dentist (1 - yes, 2 - no), child in SMA (1 - yes, 2 - no), illness or accident with the child (1 - no, 2 -yes), neonatal screening tests ( 1 - yes, 2 - no), vaccination (1 - yes, 2 - no) and notes on the Child Card (body mass, height and head circumference) and scheduling consultations (1 - yes, 2 - no).

\section{Analysis of results and statistics}

The data was processed and analyzed in the Statistical Package for the Social Sciences. Initially, a descriptive analysis of the variables was carried out in percentages to identify the type of maternal and childcare (adequate or inadequate). Therefore, the analysis was carried out by grouping variables, in which the Assistance Groups (Group I: prenatal care; Group II: maternity care; Group III: IPV consultation and; Group IV: LPR) were, respectively, renamed in Domains: Domain 1 - Prenatal; Domain 2 - Maternity;
Domain 3 - Immediate postpartum return; and Domain 4 - Late puerperal return. To analyze the domains, the percentage of $70 \%$ was used - with $\geq 70 \%$, adequate assistance; and $<70 \%$, inadequate care - a value defined in other studies that assessed the adequacy of maternal and child programs ${ }^{(6,10)}$, using the adjustment model for calculating the mean, median, standard deviation and coefficient of variance.

\section{RESULTS}

In Table 1, Domain 1 (Prenatal) shows that, of the 15 variables, only 5 were considered adequate; $71.7 \%$ started it at < 14 weeks of gestation; $85.4 \%$ had $\geq 6$ consultations, $93.6 \%$ in the FHU; $79.3 \%$ of the Pregnant Woman's Portfolio had a record of tetanus vaccination; and $72.5 \%$ had an appointment 15 days before delivery. Pregnancy was not planned for $36.1 \%$ of women; $74.5 \%$ with inadequate prenatal care; $51.5 \%$ did not receive guidance on childbirth; and $44.5 \%$ did not receive guidance on breastfeeding. Of the total, $65.8 \%$ did not undergo an obstetric clinical examination, and $84.9 \%$ did not visit the maternity ward before delivery. Almost all items to be filled in the prenatal card were classified as inappropriate.

In Domain 2, it is observed that the adequacy index in the delivery room was related to the type of delivery (74.5\%), presence of the companion (87.4\%), early mother-baby contact (86.8\%) and suction at the mother's breast in the first postpartum hour (73.1\%). In rooming-in, only breastfeeding on demand (95.5\%), healthy nipples (84.6\%) and guidance for returning to the FHU (84\%) were the variables classified as adequate.

The inadequacy in the delivery room refers to induction of delivery (43.9\%), integrity of the perineum (68.1\%) and help/ guidance for $\mathrm{BF}(34.7 \%)$. In the BFHI, the inadequacy is related to the $54.1 \%$ of NB who were referred to the BFHI one hour after delivery, to the development of problems in the breasts (41.2\%), $37.4 \%$ of which were due to nipple cleft. At the time of hospital discharge, $93.8 \%$ of NBs were not weighed, and about $48 \%$ did not receive guidance for referring breastfeeding problems.

Table 2 shows Domains 3 (Immediate puerperal return) and 4 (Late puerperal return). At the outpatient clinic, of the 16 items, only 2 were considered adequate; $81.8 \%$, attending the consultation; and $78.2 \%$, care by health professionals.

Inadequacy refers to the professional's assessment of the puerperal woman's general condition $(38.7 \%)$, of the breasts and nipples (44.5\%), breastfeeding (73.7\%), NB's body mass (90.8\%), physical examination of the NB (75.4\%) and scheduling of neonatal nursing and vaccine appointments (63.3\%). Also, the maternal and child orientations by the professional did not reach the percentage of adequacy: $92.4 \%$ regarding the care with intestinal colic; $85.7 \%$, sunbathing; $99.2 \%$, accident prevention; $79 \%$, breastfeeding; $48.5 \%$, return to the FHU for consultation; $45.4 \%$, neonatal tests; $40.6 \%$ of women did not receive information for family planning; and, in more than $52 \%$ of cases, no counter-reference was indicated.

In Domain 4, the adequacy index occurred for the child's first consultation $(92.7 \%)$, being performed by nurses $(87.4 \%)$ and pediatricians (85.2\%). There was also an adequacy for the nonoccurrence of diseases or accidents after hospital discharge (77\%), 
Table 1 - Maternal and child-care during pregnancy and delivery according to Domain 1 (Prenatal) and Domain 2 (Maternity) $(\mathrm{N}=357)$

\begin{tabular}{|c|c|c|c|c|}
\hline \multirow{2}{*}{ Variables } & \multicolumn{2}{|c|}{ Adequate } & \multicolumn{2}{|c|}{ Inadequate } \\
\hline & $\mathbf{n}$ & $\%$ & $\mathbf{n}$ & $\%$ \\
\hline \multicolumn{5}{|l|}{ Domain 1 - Prenatal care } \\
\hline Planned pregnancy & 228 & 63.9 & 129 & 36.1 \\
\hline Adequacy of prenatal care & 91 & 25.5 & 266 & 74.5 \\
\hline Beginning of prenatal care & 256 & 71.7 & 101 & 28.3 \\
\hline Number of consultations & 305 & 85.4 & 52 & 14.6 \\
\hline Place & 334 & 93.6 & 23 & 6.4 \\
\hline Guidance for childbirth & 173 & 48.5 & 184 & 51.5 \\
\hline Breastfeeding guidance & 198 & 55.5 & 159 & 44.5 \\
\hline Clinical-obstetric examination & 122 & 34.2 & 235 & 65.8 \\
\hline \multicolumn{5}{|l|}{ Filling in prenatal card } \\
\hline Prenatal problems & 163 & 45.7 & 194 & 54.3 \\
\hline Body mass control chart & 38 & 10.6 & 319 & 89.4 \\
\hline Edema evaluation & 155 & 43.4 & 202 & 56.6 \\
\hline Vaccination schedule & & & & \\
\hline Anti-tetanus & 283 & 79.3 & 74 & 20.7 \\
\hline Anti-hepatitis B & 169 & 47.3 & 188 & 52.7 \\
\hline Interval between last prenatal consultation and delivery & 259 & 72.5 & 98 & 27.5 \\
\hline Maternity visit by pregnant woman & 54 & 15.1 & 303 & 84.9 \\
\hline \multicolumn{5}{|l|}{ Domain 2 - Maternity } \\
\hline \multicolumn{5}{|l|}{ Delivery room } \\
\hline Type of delivery & 266 & 74.5 & 91 & 25.5 \\
\hline Labor induction & 204 & 57.1 & 153 & 42.9 \\
\hline Intrapartum complications & 254 & 71.1 & 103 & 28.9 \\
\hline Healthy perineum & 114 & 31.9 & 243 & 68.1 \\
\hline Companion presence & 312 & 87.4 & 45 & 12.6 \\
\hline Early mother-baby contact & 310 & 86.8 & 47 & 13.2 \\
\hline Suckling in the first postpartum hour & 261 & 73.1 & 96 & 26.9 \\
\hline Breastfeeding help/guidance in the delivery room & 233 & 65.3 & 124 & 34.7 \\
\hline \multicolumn{5}{|l|}{ Joint Accommodation } \\
\hline Referral of the new-born in the first hour & 160 & 44.8 & 193 & 54.2 \\
\hline Free breastfeeding demand & 341 & 95.5 & 16 & 4.5 \\
\hline Absence of breast problems & 210 & 58.8 & 147 & 41.2 \\
\hline Healthy nipples & 302 & 84.6 & 55 & 15.4 \\
\hline Weighing of the new-born at hospital discharge & 22 & 6.2 & 335 & 93.8 \\
\hline Local referral guidance for problems with breastfeeding & 186 & 52.1 & 171 & 47.9 \\
\hline Guidance on returning to Family Health Unit at hospital discharge & 300 & 84.0 & 57 & 16.0 \\
\hline
\end{tabular}

Table 2 - Maternal and child-care after discharge from maternity according to Domain 3 (Immediate postpartum return) and Domain 4 (Late puerperal period) $(\mathrm{N}=357)$

\begin{tabular}{|c|c|c|c|c|}
\hline \multirow{2}{*}{ Variables } & \multicolumn{2}{|c|}{ Adequate } & \multicolumn{2}{|c|}{ Inadequate } \\
\hline & n & $\%$ & $\mathbf{n}$ & $\%$ \\
\hline \multicolumn{5}{|l|}{ Domain 3 - Immediate puerperal return } \\
\hline Received care in the first 10 days & 292 & 81.8 & 65 & 18.2 \\
\hline Health professional performed care & 279 & 78.2 & 78 & 21.8 \\
\hline Assessment of the general condition of the puerperal woman & 219 & 61.3 & 138 & 38.7 \\
\hline Breast and nipple assessment & 198 & 55.5 & 159 & 44.5 \\
\hline Breastfeeding assessment & 94 & 26.3 & 263 & 73.7 \\
\hline Weighing the new-born & 33 & 9.2 & 324 & 90.8 \\
\hline Performing new-born physical examination & 88 & 24.6 & 269 & 75.4 \\
\hline Prenatal nursing and vaccine scheduling & 131 & 36.7 & 226 & 63.3 \\
\hline \multicolumn{5}{|l|}{ Maternal and child-care guidelines } \\
\hline Intestinal Colic Care & 27 & 7.6 & 330 & 92.4 \\
\hline Sunbathing & 51 & 14.3 & 306 & 85.7 \\
\hline Accident prevention & 3 & 0.8 & 354 & 99.2 \\
\hline Breastfeeding & 75 & 21.0 & 282 & 79.0 \\
\hline Prenatal nursing and vaccine & 184 & 51.5 & 173 & 48.5 \\
\hline Neonatal testing & 195 & 54.6 & 162 & 45.4 \\
\hline Family planning & 212 & 59.4 & 145 & 40.6 \\
\hline Counter-referral & 169 & 47.3 & 188 & 52.7 \\
\hline \multicolumn{5}{|l|}{ Domain 4 - Late puerperal return } \\
\hline Received support from the health professional & 167 & 46.8 & 190 & 53.2 \\
\hline First visit of the relevant child & 331 & 92.7 & 26 & 7.3 \\
\hline \multicolumn{5}{|l|}{ Family Health Unit Consultations } \\
\hline Nurse & 312 & 87.4 & 45 & 12.6 \\
\hline Paediatrician & 304 & 85.2 & 53 & 14.8 \\
\hline Dentist & 217 & 60.8 & 140 & 39.2 \\
\hline
\end{tabular}

complete neonatal tests (96.6\%), $B C G$ vaccination and scheduling of the next vaccines in the Child Card (97.2\%).

There was inadequacy in relation to professional support for the puerperal woman (53.2\%), consultation with a dentist (39.2\%), exclusive breastfeeding (53.8\%) and absence of registration in the Child Card.

In Figure 1, a decision was made to leave all the elements, since they were within a percentage scale. The variability of the domains is represented, in which a greater discrepancy can be observed in Domain 1 (Prenatal) and 3 (Immediate postpartum return), which presented the highest index of inadequacy when compared to Domains 2 (Maternity) and 4 (Return late childbirth), adequate assistance ( $\geq 70 \%$ ).

Table 3 shows a higher mean in Domain 4, with a higher adequacy index ( $\geq 70 \%)$. No 3, the lowest average. In the follow-up, the average was $<60 \%$. The median shows that Domain 4 was larger than 3 , but lower in total similar to the average. The standard deviation, greater for 3 and greater variance in relation to the mean, while, in total, the standard deviation was 9.90 , indicating that in general they are close to the mean. On the other hand, in the variance coefficient, there was an average dispersion in the 2 , 4 and total, while high in the 1 and 3 , indicating heterogeneity of the data.

\section{DISCUSSION}

The actions carried out by the health team, at all stages of the pregnancy-puerperal cycle, must take into account the conditions of life and the different forms of social insertion in the community assigned to the health unit, in order to achieve comprehensive care, a constitutional right in the country ${ }^{(11)}$. 


\begin{tabular}{|c|c|c|c|c|}
\hline \multirow{2}{*}{ Variables } & \multicolumn{2}{|c|}{ Adequate } & \multicolumn{2}{|c|}{ Inadequate } \\
\hline & $\mathbf{n}$ & $\%$ & $\mathbf{n}$ & $\%$ \\
\hline Child on exclusive breastfeeding & 165 & 46.2 & 192 & 53.8 \\
\hline Illness or accident after hospital discharge & 275 & 77.0 & 82 & 23.0 \\
\hline Complete neonatal screening tests & 345 & 96.6 & 12 & 3.4 \\
\hline Complete vaccination & 350 & 98.0 & 7 & 2.0 \\
\hline \multicolumn{5}{|l|}{ Child Card Notes } \\
\hline Body mass & 234 & 65.5 & 123 & 34.5 \\
\hline Stature & 229 & 64.1 & 128 & 35.9 \\
\hline Cephalic perimeter & 198 & 55.5 & 159 & 44.5 \\
\hline Vaccine scheduling & 347 & 97.2 & 10 & 2.8 \\
\hline
\end{tabular}

service for delivery, as well as her preparation for the guided visit until the $6^{\text {th }}$ month of pregnancy ${ }^{(2,12)}$. Guidance should be given by health professionals regarding vaginal delivery, healthy lifestyle habits, warning signs during pregnancy, care for the new-born, carrying out consultations in the puerperium and rights of the pregnant woman and the father ${ }^{(2,7)}$. However,
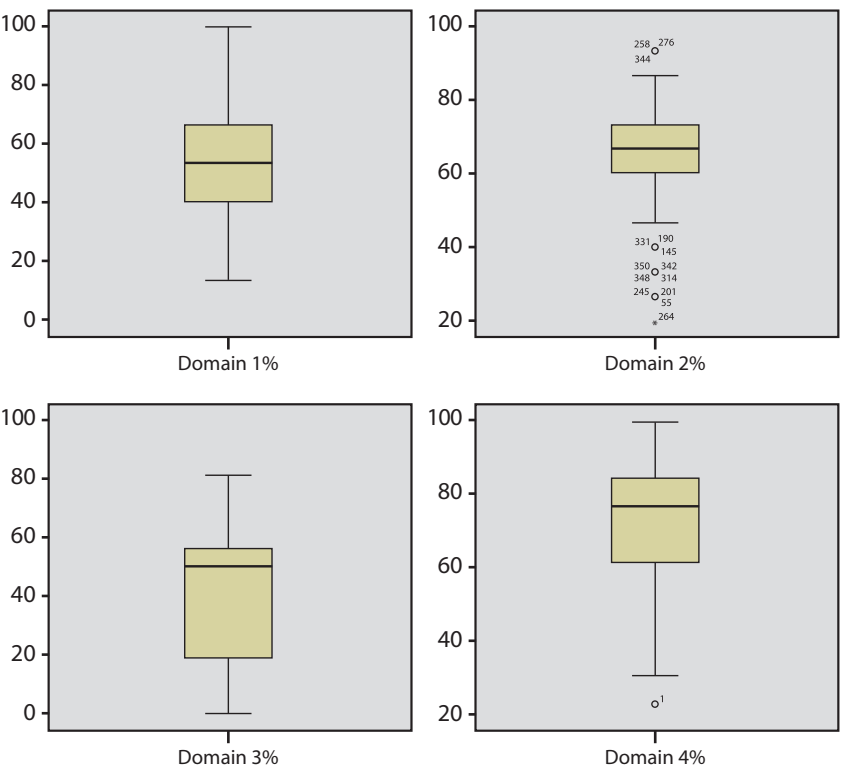

Figure 1 - Variability of Domains 1 (Prenatal), 2 (Maternity), 3 (Immediate puerperal return) and 4 (Late puerperal return)

Table 3 - Domains 1 (Prenatal), 2 (Maternity), 3 (Immediate puerperal return) and 4 (Late puerperal return) and total (follow-up) according to the adjustment model

\begin{tabular}{lrrrrr}
\hline Statistics & Domain1 & Domain2 & Domain3 & Domain4 & Total \\
\hline Mean (\%) & 52.79 & 64.86 & 39.37 & 74.82 & 57.10 \\
Median & 53.30 & 66.60 & 50.00 & 76.90 & 57.62 \\
Standard deviation & 15.92 & 13.42 & 25.18 & 15.88 & 9.90 \\
$\quad$ Maximum & 100.00 & 93.30 & 81.20 & 100.00 & 81.36 \\
Minimum & 13.30 & 20.00 & 0.00 & 23.00 & 28.81 \\
Lower limit (95\%) & 51.13 & 63.46 & 36.75 & 73.17 & 56.07 \\
Upper limit (95\%) & 54.45 & 66.25 & 41.99 & 76.48 & 58.13 \\
Coefficient of variance & 30.15 & 20.73 & 63.95 & 21.22 & 17.33 \\
\hline
\end{tabular}

Prenatal care is one of the main preventive health services used worldwide. In most Western countries, this service traditionally involves a schedule of individual visits with a health professional ${ }^{(12)}$. However, the study showed that group care was considered more acceptable than individual care, but this was not associated with adverse results (premature birth, breastfeeding, type of delivery, stress or depression, low birth weight, hospitalization in a neonatal unit and perinatal mortality), but user satisfaction was higher in group prenatal care ${ }^{(13)}$.

In Brazil, it is recommended that, during the prenatal period, this starts with the pregnant woman being linked to the hospital the present study is in agreement with another study that identified a failure in the service regarding these guidelines ${ }^{(14)}$, as well as with regard to encouraging breastfeeding, and authors point to a higher frequency of early weaning ${ }^{(15-16)}$. In developed countries in Europe, especially for the reduction of inequalities, for the effectiveness and cost-efficient in improving health and well-being after the provision of health guidelines, such actions proved to be of low evidence, as the advisors acted only as translation agents, sometimes removing barriers to prescribed behavior or helping to create enabling social environments ${ }^{(17)}$

Prenatal care, as an assistance program in the municipality under study, did not reach the desired adequacy index and recommended by the Ministry of Health, which does not differ from other Brazilian municipalities - although the cities of the states of the South Region are among the best indexes of number of consultations, even with that they still did not reach the desired and required quality ${ }^{(18)}$. Also, the registration on the Pregnant Woman's Card was below the recommended and is still a challenge in health services, therefore it is necessary to equip professionals for its use and filling, since it is a fundamental source of information between the different levels of care through which woman will pass during pregnancy, childbirth and puerperal follow-up.

In the maternity ward, care was close to that recommended by the ministerial programs, but attention should still be paid to adjustments to some items of obstetric practice, encouragement and maintenance of breastfeeding in the delivery room and rooming-in, as it is one of the public maternity hospitals in the municipality that has the title Baby Friendly Hospital Initiative.

Vaginal delivery was more frequent than surgical, but still does not meet the recommendations of the World Health Organization: a maximum of $15 \%$ of caesarean deliveries. It was also observed that unnecessary practices were also observed regarding induction of labor and perineal laceration and intrapartum complications — the highest percentage, with the foetus — , indicating that there are challenges to be overcome regarding obstetric and neonatal care. National hospital-based cohort research with puerperal women and their new-borns identified that the highest rates of neonatal mortality occurred in maternity hospitals that did not meet the quality specifications for safe delivery and birth ${ }^{(19)}$.

In the delivery room, early contact between mother and baby in the first postpartum hour is extremely important to strengthen and stimulate the emotional bond between the two. The entire health team must commit to this moment to occur and be carried out in a comprehensive manner, providing benefits not only for 
the mother and baby, but also for the whole family ${ }^{(20)}$. Such an occasion is also important for the beginning of breastfeeding, however, a low rate of this practice is perceived in hospitals in Brazil, even in those participating in the Baby Friendly Hospital initiative, which becomes a worrying reality ${ }^{(16)}$. Continuity in joint accommodation for breastfeeding on free demand favors its maintenance, reducing the risk of early weaning ${ }^{(21)}$.

Despite the widely documented risks of not breastfeeding, initiation rates remain relatively low in many high-income countries, particularly among low-income women ${ }^{(22)}$. Results of research based on scientific evidence, in European countries and the USA, showed low quality in the efficiency of different types of breastfeeding promotion activities, in terms of changing the number of women who started breastfeeding in the first hour after birth ${ }^{(22)}$. Therefore, further studies are needed in low and middle income countries to find out which strategies will encourage women to start breastfeeding right after delivery ${ }^{(23)}$.

After discharge from maternity, in the immediate postpartum period, the women in the present study did not receive adequate care. During this period, the primary care service team must perform the $\mathrm{HV}$ to monitor the general condition of the puerperal woman and the child, as well as possible signs of health problems. In such a visit, breastfeeding, care for the new-born, scheduling the second appointment with a nurse, pediatrician and dentist at the FHU should also be guided, even in the first 30 days of life, as it is during this period that the highest rates of morbimortality from infectious causes that can be detected early and treated in time ${ }^{(2,5,7)}$.

The immediate postpartum return consultation occurred for almost all women, and at the maternity clinic, but did not meet the percentage of adequacy of care and guidance for new-borns and puerperal women, as recommended by the maternal and child care networks ${ }^{(2,6,10-11)}$. The study also showed a low rate of guidance regarding new-born care, follow-up with dentistry and breastfeeding $^{(15)}$. The late puerperal return consultation was the domain that met the level of assistance adequacy in the municipality under study. Almost all mothers considered the child's consultation at the health unit relevant, and they were attended by the nurse and pediatrician, unlike the dentist. On the other hand, less than half reported not having received support from the health professional after discharge from the maternity hospital.

Maternal and child follow-up in the primary care service is still a reality far from being contemplated in the Brazilian scenario, as well as the effectiveness of health promotion actions, prevention of diseases and infant deaths, especially neonatal ones ${ }^{(11)}$. Research that evaluated the attributes of the primary care service regarding the care of children under 2 years of age, in Minas Gerais, showed that more than $80 \%$ of the interviewed caregivers evaluated with low scores ${ }^{(24)}$. On the contrary, research that also evaluated the same attributes, in Paraná, found that the best rates were those referring to primary care in FHU units, when compared to traditional ones, but concluded that it was necessary to review child-care actions in both models ${ }^{(25)}$.

The ineffectiveness of the service in late puerperal return was observed in the present study regarding exclusive breastfeeding, which showed a drop in maternity rates for the child's 42 days of life. A study carried out with nursing mothers revealed that the promotion of breastfeeding was not efficient and there was no monitoring and support for breastfeeding ${ }^{(26)}$. This fact confirms the failure to implant breastfeeding support networks, generating the need for restructuring services in order to fully and holistically serve the population of pregnant women and women who have recently given birth ${ }^{(27)}$.

The enrolment in the Children's Card also did not reach the adequacy percentage in the present study, and the results of researchers pointed to the underutilization of information ${ }^{(27-28)}$. Study shows weaknesses in the infrastructure of services, such as the lack of human resources and deficient structure of health facilities, negatively impacting the child's development ${ }^{(29)}$. However, when evaluating maternal and child health centers in Egypt, the level of quality in the organization of services and facilities available in clinics was considered good; and it has been proven that women's satisfaction is affected by the following factors: parity number, family income, as well as health professional care ${ }^{(30)}$.

Still, in Brazil, there is no adequate implementation in the daily routine of primary care services, making care a challenge, with the need to work integrally in the process ${ }^{(29-31)}$. This is reaffirmed in an international study whose objective was to identify the health promotion of primary care professionals, which showed a concentration of individual practices; however, there is little evidence on the best approaches to providing preventive care and improving health, and little attention is given in the literature to examining the impact of the organizational context on the way services are provided or on how it influences the efficiency of health improvement interventions ${ }^{(32)}$.

\section{Limitations of the study}

Longitudinal studies, although reflecting the sequence of facts, are subject to extrinsic bias, which can change the degree of comparability. Many variables in this study were analyzed, and this can often not reflect the reality of health services in terms of the user's perspective.

\section{Contributions to the area of Nursing, Health or Public Policy}

Nursing occupies most spaces in the public health system that serves all phases of the woman's reproductive period and the child's development and growth. Both groups are priorities in public policies at national and regional levels. As a contribution in this line, this study presents actions that reached adequacy index, as well as inadequacy, offering a framework based on which nursing can act in order to qualify assistance, since gaps at this level still exist in the public health service.

\section{CONCLUSIONS}

Maternal and child care in the public health service did not meet the adequacy index in all the domains analyzed. The lowest average was for Domain 3 (Immediate puerperal return) followed by Domain 1 (Prenatal) and Domain 2 (Childbirth). The only domain that reached the adequacy index was 4 , which refers to late puerperal return, but the total pregnancy-puerperal follow-up was less than $60 \%$. When detailing the assistance actions in each domain, there is a need for adjustments to reach the adequacy index at all levels of health care of the maternal and child dyad, in order to provide comprehensive care. 


\section{REFERENCES}

1. Moreira LMC, Alves CRL, Belisário AS, Bueno MC. Políticas públicas voltadas para a redução da mortalidade infantil: uma história de desafios. Rev Med Minas Gerais [Internet]. 2012 [cited 20 May 2018];22(7 Suppl):48-55. Available from: http://www.rmmg.org/artigo/detalhes/644

2. Ministério da Saúde (BR). Manual prático para a implementação da rede cegonha [Internet]. Brasília (DF): 2011[cited 20 Aug 2017]. Available from: www.saude.mt.gov.br/arquivo/3062

3. Ministério da Saúde (BR). Gravidez, parto e nascimento com saúde, qualidade de vi-da e bem-estar [Internet]. Brasília (DF): 2013[cited 20 Aug 2017]. Available from: http://bvsms.saude.gov.br/bvs/publicacoes/gravidez_parto_nascimento_saude_qualidade.pdf.

4. Mendes EV. As redes de atenção à saúde. Ciênc Saúde Coletiva. 2010;15(5):2297-305. doi: 10.1590/S1413-81232010000500005

5. Huçulak MC, Peterlini OL. G. Rede mãe paranaense: relato de experiência. Rev Es-paço Saúde [Internet]. 2014[cited 20 Aug 2017];15(1):7786. Available from: http://www.uel.br/revistas/uel/index.php/espacoparasaude/article/viewFile/18347/pdf_22

6. Frank BRB, Toso BRGO, Viera CS, Guimarães ATB, Caldeira S. Avaliação da im-plementação da Rede Mãe Paranaense em três regionais de saúde do Paraná. Saúde Debate. 2016;40(109):163-74. doi: 10.1590/0103-1104201610913

7. Ministério da Saúde (BR). Portaria GM/MS nº.1.130, 5 de agosto de 2015. Institui a política nacional de atenção integral à saúde da criança (PNAISC) [Internet]. Brasília (DF): 2015[cited 15 Aug 2017]. Available from: http://bvsms.saude.gov.br/bvs/saudelegis/gm/2015/prt1130_05_08_2015.html

8. Souza MHN, Paz EPA, Farias SNP, Ghelman LG, Mattos CX, Barros RR. Integrali-dade como uma dimensão da prática assistencial do enfermeiro no acolhimento mãe-bebê. Esc Anna Nery. 2013;17(4):677- 82. doi: 10.5935/1414-8145.20130011

9. Araújo JP, Silva RMM, Collet N, Neves ET, Toso BRGO, Viera CS. História da saú-de da criança: conquistas, políticas e perspectivas. Rev Bras Enferm. 2014;67(6):1000-7. doi: 10.1590/0034-7167.2014670620

10. Frank BRB, Toso BRGO, Viera CS, Guimarães ATB, Caldeira S. Construção e vali-dação de instrumento avaliativo de programa público de saúde materno-infantil. Ci-ênc Cuid Saude. 2016;15(1):27-35. doi: 10.4025/cienccuidsaude.v15i1.28016

11. Andrade RD, Santos JS, Maia MAC, Mello DF. Fatores relacionados à saúde da mu-lher no puerpério e repercussões na saúde da criança. Esc Anna Nery. 2015;19(1):181-6. doi: 10.5935/1414-8145.20150025

12. Catling CJ, Medley N, Foureur M, Ryan C, Leap N, Teate A, et al. Group versus conventional antenatal care for women. Cochrane Database Syst Rev. 2015;2(CD007622). doi: 10.1002/14651858.CD007622.pub3

13. Costa FJLS, Camara JT, Costa KR, Serejo ECS, Pedrosa AO, Lima AKA. Avaliação da assistência pré-natal na perspectiva da integralidade. Rev Pesqui: Cuid Fundam. 2016;8(2):4563-86. doi: 10.9789/2175-5361.2016.v8i2.4563-4586

14. Oliveira LFM, Davim RMB, Alves ESRC, Rodrigues ESRC, Nóbrega MF, Torquato JA. Vivência de puérperas adolescentes quanto à gravidez e trabalho de parto. Rev Enferm UFPE. 2016;10(2):395-406. doi: 10.5205/reuol.8557-74661-1-SM1002201603

15. Melo MM, Soares MBO, Silva SR. Orientações recebidas por gestantes adolescentes durante o pré-natal. Ciên Cuid Saude. 2015;14(3):132329. doi: 10.4025/cienccuidsaude.v14i3.24503

16. Sampaio ARR, Bousquat $A$, Barros $C$. Contato pele a pele ao nascer: um desafio pa-ra a promoção do aleitamento materno em maternidade pública no nordeste brasilei-ro com o título de hospital amigo da criança. Epidemiol Serv Saúde. 2016;25(2):281-90. doi: 10.5123/ s1679-49742016000200007

17. Carr SM, Lhussier M, Forster N, Geddes L, Deane K, Pennington M, et al. An evi-dence synthesis of qualitative and quantitative research on component intervention techniques, effectiveness, cost-effectiveness, equity and acceptability of different versions of health-related lifestyle advisor role in improving health. Health Technol Assess. 2011;15(9). doi: 10.3310/hta15090

18. Viellas EF, Domingues RMSM, Dias MAB, Gama SGN, Theme-Filha MM, Costa JV, et al. Assistência pré-natal no Brasil. Cad Saúde Pública. 2014;30(1Suppl):85-100. doi: 10.1590/0102-311X00126013

19. Lansky S, Friche AAL, Silva AAM, Campos D, Bittencourt SDA, Carvalho ML, et al. Pesquisa nascer no Brasil: perfil da mortalidade neonatal e avaliação da assistên-cia à gestante e ao recém-nascido. Cad Saúde Pública. 2014;30(Suppl):192-207. doi: 10.1590/0102-311X00133213

20. Fucks IS, Soares MC, Kerber NPC, Meincke SMK, Escobal APL, Bordignon SS. A sala de parto: o contato pele a pele e as ações para o estímulo ao vínculo entre mãe-bebê. Av enferm. 2015;33(1):29-37. doi: 10.15446/av.enferm.v33n1.47371

21. Uchoa JL, Rodrigues AP, Joventino ES, Almeida PC, Oriá MOB, Ximenes LB. Au-toeficácia em amamentar de mulheres no pré-natal e no pósparto: estudo longitudi-nal. Rev Enferm UFSM. 2016;6(1):10-20. doi: 10.5902/2179769217687

22. Balogun OO, O'Sullivan EJ, McFadden A, Ota E, Gavine A, Garner CD, et al. Inter-ventions for promoting the initiation of breastfeeding. Cochrane Database Syst Rev. 2016;11(CD001688). doi: 10.1002/14651858.CD001688.pub3

23. Lumbiganon P, Martis R, Laopaiboon M, Festin MR, Ho JJ, Hakimi M. Antenatal breastfeeding education for increasing breastfeeding duration. Cochrane Database Syst Rev. 2016;12(CD006425). doi: 10.1002/14651858.CD006425.pub2

24. Mesquita-Filho M, Luz BSR, Araújo CS. A atenção primária à saúde e seus atribu-tos: a situação das crianças menores de dois anos segundo suas cuidadoras. Ciênc Saúde Coletiva. 2014;19(7):2033-46. doi: 10.1590/1413-81232014197.17322013 
25. Oliveira VBCA, Veríssimo MR. Children's health care assistance according to their families: a comparison between models of Primary Care. Rev Esc Enferm USP. 2015;49(1):30-6. doi: 10.1590/S0080-6234201500001000

26. Vargas GS, Alves VH, Rodrigues DP, Branco MBLR, Souza RMP, Guerra JVV. Atuação dos profissionais de saúde da estratégia saúde da família: promoção da prá-tica do aleitamento materno. Rev baiana enferm.2016;30(2):1-9. doi: http://dx.doi.org/10.18471/rbe.v30i2.14848

27. Almeida AC, Mendes LC, Sad IR, Ramos EG, Fonseca VM, Peixoto MVM. Uso de instrumento de acompanhamento do crescimento e desenvolvimento da criança no Brasil: revisão sistemática de literatura. Rev Paul Pediatr. 2016;34(1):122-31. doi: 10.1016/j. rppede.2015.12.002

28. Oliveira MFS, Martinez EZ, Rocha JSY. Fatores associados à cobertura vacinal em menores de cinco anos em Angola. Rev Saúde Pública. 2014;48(6):906-15. doi: 10.1590/S0034-8910.2014048005284

29. Silva DI, Verissimo MR, Mazza VA. Vulnerabilidade no desenvolvimento infantil: influência das políticas públicas e programas de saúde. Rev bras crescimento desen-volv hum. 2015;25(1):11-8. doi: 10.7322/JHGD.96760.

30. Mohamed SA, Mohamed AG, Arief AF. Women Satisfaction with Family Planning Services in Maternal and Child Health Centers, Assiut City, Egypt. Am J Nurs Res. 2017;5(3):79-85. doi: 10.12691/ajnr-5-3-2

31. Duarte ED, Sena RR, Dittz ES, Tavares TS, Silva PM, Walty CMRF. A integralidade do cuidado ao recém-nascido: articulações da gestão, ensino e assistência. Esc Anna Nery. 2013;17(4):713-20. doi: 10.5935/1414-8145.20130016

32. Peckham S, Falconer J, Gillam S, Hann A, Kendall S, Nanchahal K, et al. The or-ganization and delivery of health improvement in general practice and primary care: a scoping study. Health Serv Delivery Res. 2015;3(29). doi: 10.3310/hsdr03290 